\title{
THE INFLUENCE OF A PREGNANT WOMAN'S SOCIAL WELL-BEING ON THE QUALITY OF HER LIFE
}

\author{
Kseniya V. Kuleshova \\ First I.M. Sechenov Moscow State Medical University \\ Moscow, Russia
}

The quality of a pregnant woman's life in Russia is usually much lower than in any European country. Because of this situation it is most important to look for psychological resources that could enable pregnant women to have a higher quality of life. My empirical research showed that pregnant women who are not officially married feel fear and anxiety during their pregnancy more often than those who are married. There are statistically relevant differences between the control group (the group of officially married pregnant women) and unmarried pregnant women in their level of comfort during pregnancy. Unmarried pregnant women also feel such emotions as guilt, remorse, shame, and shyness more often (these data were obtained by means of C.E. Izard's method). Data obtained through a clinical interview showed that pregnant women who are not married often feel that they are not being protected by society, have financial problems, and experience pain during the delivery of the child. They also feel guilt when they think of bringing up their children ("I won't be able to give my child all those things that I could possibly give him or her if I were married"); and they are quite often ashamed of their pregnancy when they communicate with their parents and other relatives and with their friends, acquaintances, and doctors. The research showed no direct influence of such factors as the material wealth of a pregnant woman's family on her emotional state. The number of children that women expect to have depends on their level of education but not on the level of the material wealth of their families.

Keywords: a pregnant woman, social well-being, an emotional state.

According to the data from the latest general census of the population, more than $53 \%$ of those who live in Russia are women. About $45.7 \%$ of these women (i.e., 36 million women) are 15-49 years old and are able to give birth to children, thus performing one of their most important biological and social functions. 
Yet, the reproductive health of women living in Russia is deteriorating. The quality of life of pregnant women in Russia is lower than in European countries (Animtsa, Yolohov, \& Suhih, 2000; Kuleshova, 2011). Thus, research on the psychological aspects of reproductive health and the psychological resources that could be used to make the quality of pregnant women's life better is urgent and important at this time. This kind of knowledge would make it possible to improve psychological help to pregnant women and to increase the level of the psychological competence of the specialists involved.

Health is a complicated, multidimensional phenomenon, consisting of various components that differ in quality. Health reflects fundamental aspects of human existence. The complexity and heterogeneity of the structure of health are emphasized in the definition given by the experts of the World Health Organization: "Health is a state of complete physical, psychic and social well-being and not only the absence of any diseases or defects" (see: Dartau, Mizernitsky, \& Stefanyuk, 2009, p. 12-13). A state of well-being, of being satisfied with one's life, including one's position in various spheres of life, is a most important indicator of the quality of life of a pregnant woman.

Nowadays, pregnancy is considered to be a natural (and not a pathological) state. It is one of the physiological, psychological, social, and spiritual events in life that are quite normal, just a part of the process. Pregnancy (no matter whether it is desired and planned in advance or not) always means change for a woman. It affects all the spheres of her life. The health of a pregnant woman (by which we mean a state of physical, psychic, and social well-being and not just the absence of some kind of physiological defects in the course of pregnancy) can become a goal that needs to be reached not only by her but also by her family and by the whole society. Not only the resources of her body and her personality and not only her conscious efforts (her inner activity and her activity in the outer world) but also the efforts of her family and the society she lives in are necessary for this goal to be reached.

In our empirical research, my colleagues and I studied the influence of a pregnant woman's social well-being on subjective indicators of the quality of her life during her pregnancy. We consider the quality of a person's emotional state to be one of the most important subjective indicators of the quality of life. The research consisted of two stages. 


\section{The First Stage of the Empirical Research}

The influence of factors connected with a pregnant woman's family situation on her experience of her pregnancy has been studied in a number of psychological research projects. Zaharov (1997) found out that some of the reasons for emotional stress during pregnancy are a woman's doubts about the durability and the safety of her marriage and problems in her relationship with her spouse. Women who have miscarriages have problems in their relationships with other members of their families and feel less supported by their families and society than do those who have such support. Family support creates a "buffer effect" and is an important factor that should be taken into account in order to prevent stress connected with pregnancy. The health of a pregnant woman is influenced by her husband's attitude to her pregnancy and by the views and attitudes of other family members. She needs to feel that if she is not able to bear her child or if the child dies during delivery, she will not be left alone and will be supported and helped through this experience.

Pregnancy actually means that a woman accepts and raises something that her man "has given" her. It can have various meanings for women depending on whether they are officially married and their men are their spouses. If the father of the child is the woman's husband or partner, the kind of relationship she had with him before the conception is important for her. Expecting a child implies a lot of changes in the life of a couple (Avksentyeva, 1994; Volovik, 1980).

In the last 3 months of pregnancy, all the emotions connected with the social and psychological situation of a pregnant woman contribute to the overall feeling of anxiety caused by the pregnancy as such. This anxiety may be caused by physiological changes in the woman's body, which she cannot control. Anxiety can occur in spite of the fact that the woman is experiencing quite strong positive feelings at the same time (Land, 2003).

Fear and overall anxiety can increase right before delivery if the woman is expecting some kind of trouble or disaster during the birth of the child or immediately after it (Volovik, 1980).

Mendelevich (2001) describes the phenomenon of perinatal anxiety and the kinds of such anxiety, which are: (1) generalized; (2) physical, when a woman can hardly bear the physical processes that take place during pregnancy; (3) fear for the baby and what happens to it; (4) fear of 
all the responsibilities connected with taking care of the newborn child; (5) fear of the delivery process; (6) fear of feeding the baby; (7) psychopathological.

We wanted to see whether a factor such as being officially married during a pregnancy could influence the quality of a woman's life as estimated with the help of indices of her emotional state.

\section{Hypotheses}

1. Pregnancy is more often seen as a difficult and challenging situation, giving rise to strong emotions, by those women who are not officially married than by those who are married.

2. Women who are not officially married experience less comfort connected with pregnancy during the last 3 months than do those who are married.

3. The level of both personal and situational anxiety during the last 3 months of pregnancy is higher in those women who are not officially married than in those who are married.

\section{Cite of the Research}

This research was conducted in the Clinic of Obstetrics and Gynecology of the I.M. Sechenov Moscow Medical Academy.

\section{Subjects}

During the research, 30 pregnant women were questioned.

The main group consisted of 15 women who were not officially married. Their age varied from 19 to 25 . All were to give birth to a child for the first time and their pregnancy was by chance (not planned in advance). All reported that the baby was a desired one. Three of the women had a higher education; six women had a secondary education with specialization; five women had a comprehensive secondary education; and one was completing her higher education. Their professional status was the following: one woman was a student, seven women were housewives, four women were shop assistants, three women worked with computers. None of them had houses or apartments of their own: 13 women shared apartments with their parents, 2 women rented rooms. The incomes of two women were average; the incomes of five women were lower than average; eight women had no income of their own (their parents provided for them). 
The control group consisted of 15 women who were officially married; they were chosen at random. Their age varied from 21 to 25 . All of them were to give birth to a child for the first time too. The pregnancies of nine women had been planned in advance, six women were pregnant by chance. All said that they wanted the baby. Eight women had a higher education; six women had a secondary education with specialization; and one woman was completing her higher education. Their professional status was the following: one woman was a student, six women were managers or lawyers, two women worked in the field of medicine, three women worked with computers, three women were housewives. All considered their family income to be average and their living conditions to be good. All lived with their husbands in their own apartments.

\section{Methods}

The research had three parts:

First Part. The women filled in forms in which biographical questions were asked.

Second Part. The following psychodiagnostic methods were used:

- Differential Emotions Questionnaire of C.E. Izard.

- Reactive and Personal Anxiety Scale of C.D. Spilberg and Y.L. Hanin.

- Method of Psychic Activation, Interest, Emotional Tone and Tension of N.A. Kurgansky.

Third Part. Clinical interviews were conducted.

\section{Results}

- There was no valid statistical difference in the levels of personal and situational anxiety (accessed with the Spilberg-Hanin Scale) between the main and the control groups (those pregnant women who were not officially married and those pregnant women who were). (The 1-criterion of the student was used.)

Yet a qualitative analysis of various emotions, made using Izard's method, showed that this difference exists: women who were not officially married felt fear and anxiety more often $(1>2.1 ; P>95 \%)$.

These results do not allow us to either prove or disprove the third hypothesis of our empirical research. This research needs to be continued. 
- The level of comfort connected with pregnancy was definitely lower in the main group than in the control group $(1>2.1 ; P>95 \%)$. This finding proves the second hypothesis of our empirical research.

- The pregnant women who were in the main group felt guilt, remorse, fear and anxiety, shame, and shyness more often than those in the control group $(1>2.1 ; P>95 \%)$. (These data were obtained using Izard's method.) The clinical interviews showed that the pregnant women who were not officially married more often felt the fear of not being sufficiently protected by society and had financial problems (14 women; $93.3 \% \pm 6.5)$. One woman felt the fear of pain during the process of birth $(6.7 \% \pm 3.2) ; 13$ women $(86.6 \% \pm 9.1)$ felt guilt and remorse when they thought about bringing up their children ("I won't be able to give my child all the things that I could possibly give him or her if I were married"). Two women $(13.4 \% \pm 6.8)$ felt guilt in their relationship with their parents. All the women in this group felt shame. They were ashamed of their pregnancy when they communicated with their parents and other relatives and with their friends, acquaintances, and doctors. Shame was thus experienced in their relationships with the whole society. So, the first hypothesis of our empirical research was proved.

Thus, the family status of a pregnant woman does influence her pregnancy. From a psychological point of view, pregnancy is a difficult situation for a woman who is not officially married. (It is possible to suppose that some disorders could occur in the formation of the gestational dominant, and the result could be somatic complications during the pregnancy. The research needs to be continued in order to prove this supposition). However, it is necessary for such women to have social support to enable them to handle their fear, tension, guilt, shame, and other negative emotions that they are likely to have.

\section{The Second Stage of the Empirical Research}

\section{Hypothesis}

The emotional state of a pregnant woman depends on the financial well-being of her family.

\section{Methods}

1. The Differential Emotions Scale of Izard was used as a diagnostic method for determining situational emotional states. 
2. I.V. Dobryakov's questionnaire was used to diagnose nervous or psychic disorders in the pregnant women.

3. The women filled in a form with questions about their social status and the financial well- being of their family.

4. We observed the women.

\section{Cite of the Research}

This research was done in the Clinic of Obstetrics and Gynecology of the I.M. Sechenov Moscow Medical Academy.

\section{Subjects}

Our subjects were 50 pregnant women. Their ages varied from 18 to 40 years. All of them lived in Moscow and in the Moscow area.

We formed two experimental groups. The first one consisted of pregnant women whose families had the lowest level of financial well-being, although there were no women whose family income was lower than the living wage in this group. So, the women in the first group had an average material level, but it was lower in comparison with the material level of those in the second group. The second group consisted of pregnant women whose family had financial well-being that was higher than average.

The percentage of women who were officially married was almost the same in both groups $(80 \%$ in the first one and $74 \%$ in the second one). In both groups, women mostly lived in Moscow and had apartments of their own.

There was some slight difference in the level of education: $92 \%$ of women in the first group had a higher education, while $76 \%$ of the second group did; so, the level of education of the first group of women was higher. Only $8 \%$ of the women in the first group had a secondary education, and $24 \%$ of the women in the second group did.

In both groups most women were not very young: they were more than 30 years old (23 women in both groups) or were 26-30 years old ( 20 women in both groups). The majority of the women in both groups (80\%) made a conscious decision to have the baby and not to have an abortion; and $20 \%$ of the women in both groups said that they had been compelled not to have an abortion. One of the women in the first group reported that she didn't want to have the baby; her pregnancy was undesirable. 
Among the pregnant women whose level of financial well-being was higher than average, 21 women $(84 \%)$ were older than $25 ; 14$ women (56\%) were having a baby for the first time; 21 women (84\%) had planned this pregnancy in advance and it was a desired one. Among the pregnant women whose level of financial well-being was lower, 13 women (52\%) were older than $30 ; 14$ women (56\%) had more than two pregnancies; 17 women (68\%) had not given birth to a child yet; and 19 women (76\%) had planned their pregnancy in advance and it was a desired one.

In both groups, most of the women were not addicted to either nicotine or alcohol (45 women, $90 \%$ ), had an active live style, and, on the whole, were quite satisfied with their life.

Paying for medical services during pregnancy was also taken into account.

\section{Results}

- Most of the women experienced positive emotions in connection with their pregnancy (as determined with Izard's method). Positive emotions were stronger than negative ones in both experimental groups. No significant difference in the quality of emotional experience between the women in the two experimental groups was found using Izard's method.

- The data obtained with the help of questionnaires showed that the ideal, desired, and expected number of children mentioned by the women in both experimental groups became higher as the level of education increased. In both groups, the number of expected children mentioned by those pregnant women who had a secondary education was lower than the number mentioned by those women who had a higher education (or were studying in a higher education institution). Thus, these data showed that the number of expected children in a family depends not on the financial well-being of the family but on the women's level of education.

- In both experimental groups, most of the women had the optimal type of psychological component of the gestational dominant. Still, the number of such women was higher in the group of those whose level of material wealth was higher than in the group of those whose level of material wealth was lower. This finding most likely tells us that those women whose material level was higher took their pregnancy easier. They worried about the future of their child less, everything was all right in their families, they were less anxious because of their work. They had 
already solved many of their professional and, consequently, their financial problems before they got pregnant. These data showed that the financial level of the family does influence the pregnant woman's attitude toward her baby and her pregnancy.

- No significant difference in the emotional state of the women was found in connection with paying for medical services during pregnancy. Women whose financial status was not so high may have chosen to pay for medical services during pregnancy and may have preferred the services of private specialists to the services they could have received in state medical institutions for free. It was not the payment for medical services but the financial level of a woman's family that influenced her emotional state during pregnancy.

Thus, the influence of the financial well-being of a woman's family on her emotional state during pregnancy was found out to be a complicated one. Further research is needed.

On the whole, both stages of our empirical research showed that the social well-being of a pregnant woman does influence her psychic wellbeing and the quality of her life as assessed by indices of her emotional state.

\section{References}

Animtsa, E.G., Yolohov, A.N., \& Suhih, V.A. (2000). Kachestvo zhizni naseleniya krupneishego goroda [The quality of life of the inhabitants of the biggest city] (Part 1). Yekaterinburg: Publishing House of the Ural State Economics University.

Avksentyeva, M.V. (1994). Sem'ja i bolezn [Family and disease]. Moscow: Medical Bulletin.

Dartau, L.A., Mizernitsky, Yu.L., \& Stefanjuk, A.P. (2009). Zdorovje cheloveka $i$ kachestvo zhizni: problemi i osobennosti upravleniya [Human Health and the Quality of Life: Problems and Peculiarities of Control]. Moscow: SINTEG.

Kuleshova, K.V. (2011). Period Beremennosti kak vozmozhnost' samoaktualizatsii I duhovnogo blagopoluchija zhenshchiny [The Period of Pregnancy as an Opportunity of Self Actualization and a Woman's Spiritual Well-being]. In D.B. Bogoyavlenskaya, \& Yu.P. Zinchenko (Eds.), 125 let Moskovskomu psihologicheskomu obschestvu: yubileini sbornik RPO, t. 3 [125 years of Moscow Psychological Society: Anniversary Collection of works, vol. 3] (pp. 193-195). Moscow: MAKS Press.

Land, P. (2003). "Otnoshenie zhenschin k svoemu telu" [Women's attitude toward their bodies]. In M. Lourens \& M. Maguir (Eds.), Psihoterapiya zhenschin [Psychotherapy of women] (pp. 63-78). St. Petersburg: Piter. 
Mendelevich, V.D. (2001). Klinicheskaya i meditsinskaya psihologiya: Prakticheskoe rukovodstvo [Clinical and medical psychology: A manual for practitioners]. Moscow: MEDpress.

Volovik, V.M. (1980). Semeynie issledovaniya $v$ psihiatrii $i$ ih znachenie dlya reabilitatsii bol'nih [Family research in psychiatry and its meaning for the rehabilitation of patients]. Moscow: Meditsina

Zaharov, A.I. (1997). Vliyanie emotsional'nogo stressa materi na techenie beremennosti i rodov [The influence of the mother's emotional stress on the course of pregnancy and birth]. In Perinatal'naja psihologija $v$ rodovspomozhenii [Perinatal psychology in obstetric aid] (pp. 54-56). St. Petersburg: St. Peterburg State University. 